Pediatric

Neurosurgery
Pediatr Neurosurg 2000;32:57

\section{Development of Pediatric Neurosurgery}

\author{
David G. McLone, Editor-in-Chief
}

This issue of Pediatric Neurosurgery contains an essay by Ken R. Winston on the history of and arguments for subspecialization in pediatric neurosurgery. 'Pediatric Neurosurgery: Pride and Prejudice' makes a clear argument for the development of subspecialties within surgical practice and defines the role of societies and periodicals in its development. It also makes it clear that the beneficiary of this progress is the child.

Pediatric Neurosurgery has published 3 Presidential Addresses on this same topic. It is important that we periodically revisit this issue. We must keep a clear eye on the prize, better care for children with surgical problems of the nervous system. Only with participation and advocacy by us pediatric neurosurgeons through research and publication will this evolutionary process move toward better care.

\section{KARGER}

Fax +4161306 1234

E-Mail karger@karger.ch

www. karger.com (c) 2000 S. Karger AG, Basel

1016-2291/00/0322-0057\$17.50/0

Accessible online at:

www. karger.com/journals/pne 